ROCZNIKI NAUK PRAWNYCH

Tom XXIX, numer $1-2019$

DOI: http://dx.doi.org/10.18290/rnp.2019.29.1-3

PIOTR KOBYLSKI

\title{
POSTANOWIENIA UMOWY KREDYTU INDEKSOWANEGO \\ DO WALUTY OBCEJ LUB DENOMINOWANEGO W WALUCIE OBCEJ - STUDIUM PROBLEMU
}

\section{WSTĘP}

Niniejsze opracowanie zostało poświęcone zagadnieniu umowy o kredyt indeksowany lub denominowany do waluty innej niż waluta polska. Problem przeliczania waluty według kursu arbitralnie ustalonego przez bank to dylemat, z którym boryka się dziś spora liczba kredytobiorców. Znaczna liczba osób zaciągających kredyty hipoteczne w obcej walucie to konsumenci. W związku z czym $\mathrm{z}$ uwagi na swój status podlegają oni ustawowo ochronie prawnej. W myśl art. $22^{1}$ Kodeksu cywilnego ${ }^{1}$, za konsumenta uważa się osobę fizyczną dokonującą z przedsiębiorcą czynności prawnej niezwiązanej bezpośrednio z jej działalnością gospodarczą lub zawodową.

Opracowanie koncentruje się na tzw. „kredytach frankowych”, których wzrost nastąpił w 2005 r. Niskie oprocentowanie franka szwajcarskiego (CHF), przy relatywnie niskich ratach, w stosunku do kredytów złotowych, spowodowało, iż kredytobiorcy chętnie zaciągali kredyty w wysokiej kwocie. Problem „kredytów frankowych" został dostrzeżony w drugiej połowie 2008 r., kiedy rozpoczął się systematyczny wzrost kursu CHF/PLN. Efektem zmian był wzrost zarówno rat, jak i salda zadłużenia wyrażonego w złotych ${ }^{2}$.

Mgr PIOTR KobYLSKI - doktorant w Katedrze Prawa Administracyjnego, Instytut Prawa, Wydział Prawa, Prawa Kanonicznego i Administracji Katolickiego Uniwersytetu Lubelskiego Jana Pawła II, Al. Racławickie 14, 20-950 Lublin; e-mail: piotrkobylski@gmail.com; https://orcid.org/ 0000-0002-0345-904X

${ }^{1}$ Ustawa z dnia 23 kwietnia 1964 r. - Kodeks cywilny, Dz. U. z 2018 r., poz. 398 [dalej cyt.: Kodeks cywilny].

${ }^{2}$ A. BAREMBUCH, Kredyt frankowy a kredyt ztotowy - perspektywa zmian clash-flow, „Finanse, Rynki Finansowe, Ubezpieczenia” 82 (2016), nr 4, cz. 2, [w:] http://www.wneiz.pl/nauka_wneiz/ frfu/82-2016/FRFU-82-cz2-805.pdf [dostęp: 9.04.2018], s. 805. 
Mając powyższe na uwadze, po pierwsze należy zaznaczyć, że kształt umowy kredytu ulega ustawowemu ograniczeniu na podstawie przepisów Prawa bankowe$\mathrm{go}^{3}$. Mianowicie bank zobowiązuje się oddać do dyspozycji kredytobiorcy na czas oznaczony w umowie kwotę środków pieniężnych z przeznaczeniem na ustalony cel, a kredytobiorca zobowiązuje się do korzystania z niej na warunkach określonych w umowie, zwrotu kwoty wykorzystanego kredytu wraz z odsetkami w oznaczonych terminach spłaty oraz zapłaty prowizji od udzielonego kredytu. Warto dodać, iż ustawodawca wprost podał obligatoryjne postanowienia, które powinny znaleźć się w umowie kredytowej. Przede wszystkim jest to kwota i waluta kredytu, jak również zasady i termin spłaty kredytu. Do obowiązkowych postanowień należą również w sytuacji umowy o kredyt denominowany lub indeksowany do waluty innej niż polska, konkretne reguły określania sposobów i terminów ustalania kursu wymiany walut, na podstawie którego wyliczana jest kwota kredytu, jego transza oraz raty kapitałowo-odsetkowe. Katalog obowiązkowych postanowień zamyka wysokość oprocentowania kredytu i warunki jego zmiany. Art. 69 § 3 Prawa bankowego pozwala kredytobiorcy na spłatę zobowiązania kredytowego wprost w walucie kredytu.

Fundamentalną dla prawa cywilnego, a fortiori dla umowy kredytu, jest zasada pacta sunt servanda. Prezes Urzędu Ochrony Konkurencji i Konsumentów wskazał, że „przeciętny konsument ma prawo oczekiwać, że bank dotrzyma postanowień zawartej z nim umowy zgodnie z dobrymi obyczajami kupieckimi. Co istotne, twórcami postanowień umów, do których w ramach adhezji przystępowali konsumenci, były właśnie banki" ${ }^{4}$. Opracowanie zamierza udowodnić, że kredytodawca w znacznej ilości przypadków w przypadku umowy kredytu indeksowanego do waluty obcej lub denominowanego w walucie obcej nie naruszył konstrukcji prawnej umowy kredytowej jako umowy odpłatnej. Bowiem banki, „,wskazując w treści umów, że oprocentowanie będzie ustalane według formuły LIBOR CHF + marża, nie zastrzegły, że umowy w tym zakresie wykonywane będą przy uwzględnieniu innych czynników (tj. tych, które zdaniem banków wynikają z treści przepisów prawa), a miały obowiązek zapewnienia konsumentom jasnej i rzetelnej informacji na podstawie" ${ }^{\text {. }}$ Oznacza to, że przedmiotem badania

\footnotetext{
${ }^{3}$ Art. 69 ustawy z dnia 29 sierpnia 1997 r. Prawo bankowe, Dz. U. z 2018 r., poz. 138 [dalej cyt.: Prawo bankowe].

${ }^{4}$ RAPORT RZECZNIKA FINANSOWEGO, Analiza prawna wybranych postanowien umownych stosowanych przez banki w umowach kredytów indeksowanych do waluty obcej lub denominowanych w walucie obcej zawieranych z konsumentami, [w:] https://rf.gov.pl/pdf/Raport_RF_Kredyty_walutowe.pdf [dostęp: 1.01.2018], s. 93.

${ }^{5}$ Tamże, s. 92.
} 
będzie kwestia abuzywności postanowień umownych w umowach kredytu indeksowanego do waluty obcej lub denominowanego w walucie obcej. Praca zmierza do wykazania, iż kredytobiorcy powinni wystąpić na ścieżkę sądową przeciwko kredytodawcy w sytuacji uznania, że postanowienie umowy kredytu nieuzgodnione indywidualnie kształtuje jego prawa i obowiązki w sposób sprzeczny z dobrymi obyczajami, rażąco naruszając jego interesy.

Przedmiot opracowania i wyznaczone cele przesądziły o wyborze układu opracowania i metod badawczych. Podstawowym źródłem badawczym będą zatem określone akty normatywne, takie jak: ustawa z dnia 23 kwietnia 1964 r. Kodeks cywilny oraz ustawa z dnia 29 sierpnia 1997 r. - Prawo bankowe. Artykuł składać się będzie ze wstępu, rozwinięcia oraz zakończenia. W drugiej części opracowania uwzględnione będą trzy podpunkty, w których odpowiednio przeanalizowane będą szczegółowo: umowa kredytu, abuzywność postanowień umownych w umowie kredytu oraz kryteria ustalania kursu CHF.

Zawarte w pracy uwagi zostaną przeprowadzone w oparciu o metodę dogmatyczną odniesioną do konkretnych regulacji normatywnych. W pracy zostanie dokonana nie tylko analiza określonych norm prawnych, lecz także orzecznictwa sądów powszechnych.

\section{UMOWA KREDYTU}

W punkcie wyjścia trzeba odnotować, że kredyty bankowe w Polsce udzielane są najczęściej w walucie polskiej, ale również mogą być udzielane jako kredyty nominowane w walutach obcych. Kwota kredytu wówczas jest wyrażona w walucie obcej, natomiast przekazanie środków i ich spłata następuje w walucie polskiej z zastosowaniem właściwego kursu walutowego ${ }^{6}$. „Pojęcie kredytów «frankowych» jest sformułowaniem potocznym i dotyczy kredytów złotowo-walutowych, waloryzowanych (denominowanych lub indeksowanych) kursem szwajcarskiej waluty"7. W kredycie denominowanym waluta kredytu określana jest w walucie obcej (CHF), natomiast kwota kredytu wyrażona w CHF jest znana z góry w momencie zawarcia umowy. Kredyt indeksowany zaś charakteryzuje się tym, że waluta kredytu jest wyrażona w PLN, a kwota kredytu określona w walucie krajowej (PLN) jest znana z góry w momencie zawarcia umowy, a następnie indeksowana kursem waluty obcej w dniu wypłaty kredytu.

\footnotetext{
${ }^{6}$ Z. OfIARSKI, Prawo bankowe. Komentarz LEX, Warszawa: Wolters Kluwer 2013, s. 489.

${ }^{7}$ BAREMBUCH, Kredyt frankowy, s. 806.
} 
Ustalenie w umowie kredytowej kwoty oznacza, że jest to maksymalna kwota środków pieniężnych, które bank pozostawia do dyspozycji kredytobiorcy. Po stronie kredytobiorcy nie powstaje obowiązek wykorzystania całej kwoty kredytu. Może on zrezygnować z określonej części kredytu, nawet już po uruchomieniu pewnej jego kwoty. W wyniku uzgodnienia zmiany umowy przez jej strony możliwe jest także podwyższenie kwoty kredytu. Ustawodawca dokonał regulacji, stanowiąc, jakie niezbędne postanowienia powinny być zawsze wskazane w umowie bankowej (art. 69 ust. 2 Prawa bankowego). Należą do nich m.in. kwota i waluta kredytu. Wyodrębnienia wymagają także zasady oraz termin spłaty kredytowej. Natomiast w sytuacji umowy o kredyt denominowany lub indeksowany do waluty innej niż waluta polska trzeba podkreślić szczegółowe zasady określania sposobów i terminów ustalania kursu wymiany walut, na podstawie którego wyliczana jest kwota kredytu, jego transza, raty kapitałowo-odsetkowe oraz zasady przeliczania na walutę wypłaty albo spłaty kredytu. Ponadto istotna jest wysokość oprocentowania kredytu i warunki jego zmiany. Warto w tym miejscu zaznaczyć, iż w związku z tzw. ustawą antyspreadowa obowiązującą od dnia 26 sierpnia $2011 \mathrm{r}$. został powiększony opisywany katalog ${ }^{8}$. Ustawodawca dodał do obligatoryjnych składników umowy kredytowej postanowienia dotyczące kredytu indeksowanego lub denominowanego do waluty innej niż waluta polska. Ponadto ustawodawca zadecydował, że kredytobiorca może dokonać spłaty zobowiązania kredytowego wprost w walucie kredytu (art. 69 § 3 Prawa bankowego). Warto zaznaczyć, że nie wszystkie z tych elementów stanowią essentialia negotii umowy bankowej. Przez umowę kredytu bank zobowiązuje się oddać do dyspozycji kredytobiorcy na czas oznaczony w umowie kwotę środków pieniężnych z przeznaczeniem na ustalony cel, a kredytobiorca zobowiązuje się do korzystania z niej na warunkach określonych w umowie, zwrotu kwoty wykorzystanego kredytu wraz z odsetkami w oznaczonych termiach spłaty oraz zapłaty prowizji od udzielonego kredytu. Innymi słowy, bank zobowiązuje się do wydania określonej sumy, a kredytobiorca do zwrotu wykorzystanej sumy kredytu i zapłacenia odsetek kapitałowych. Świadczeniem głównym kredytobiorcy jest zwrot otrzymanych środków pieniężnych, uiszczenie opłat z tytułu oprocentowania i z tytułu prowizji. Należy również zaznaczyć, że czym innym jest postanowienie wskazujące główne świadczenie stron umowy kredytu, a czym innym metoda przeliczenia kwoty kredytu czy raty kredytu.

\footnotetext{
${ }^{8}$ Ustawa z dnia 29 lipca 2011 r. o zmianie ustawy - Prawo bankowe oraz niektórych innych ustaw, Dz. U. poz. 984.
} 
W związku z powyższym, kredyt denominowany to kredyt udzielony w walucie polskiej. Należy zauważyć, iż rozliczenia między bankiem a klientem nie są prowadzone w walucie obcej. Bank wypłaca transze kredytu w złotówkach, jak również w złotówkach klient spłaca kredyt. Nie jest to więc kredyt walutowy, ale kredyt udzielany w walucie polskiej. Świadczenie główne kredytobiorcy jest świadczeniem w polskiej walucie, a zostaje wyłącznie przeliczone na walutę obcą. Wobec tego kredyty denominowane określają pewien mechanizm postępowania, który może być przedmiotem badania z punktu widzenia abuzywności. Dodatkowo należy także zaznaczyć, iż na ogół umowa kredytu nie zawiera jednej zmiennej wartości, czyli kursu danej waluty, lecz także inne zmienne, jak np. oprocentowanie. Wobec tego oprocentowanie jest ustalane według zmiennej stopy procentowej'.

W literaturze przedmiotu wskazuje się, że bank może stosować stałą lub zmienną stopę oprocentowania, jednak w razie stosowania stopy zmiennej należy określić w umowie kredytu warunki zmiany stopy procentowej kredytu oraz powiadomić w sposób określony w umowie kredytobiorcę ${ }^{10}$. Klauzula zmiennego oprocentowania nie może mieć charakteru blankietowego, ale powinna dokładnie wskazywać okoliczności faktyczne usprawiedliwiające zmianę oprocentowania oraz relację między zmianą tych czynników a rozmiarem zmiany stopy oprocentowania kredytu, określając precyzyjnie wpływ zmiany wskazanych okoliczności na zmianę stopy procentowej. Niedopuszczalna jest klauzula umowna przyznająca bankowi uprawnienie do dokonywania w dowolnym czasie dowolnych zmian treści umowy. Prowadziłoby to bowiem do rażącego uprzywilejowania banku jako partnera stosunku cywilnoprawnego. Ustalenie zmiennej stopy oprocentowania, mimo iż umożliwia przeniesienie części ryzyka kredytodawcy związanej ze zmianami gospodarczymi na konsumenta, powinno być tak unormowane w umowie, aby w chwili zawarcia umowy konsument mógł dokonać oceny celowości i opłacalności zaciągniętego kredytu. Prawo bankowe jednak nie precyzuje sposobu ustalania warunków, od których zaistnienia bank może dokonywać zmiany wysokości oprocentowania ${ }^{11}$.

W przypadku umowy kredytu indeksowanego występuje także udostępnienie sumy kredytu kredytobiorcy i zwrotu wykorzystanej sumy w ratach kredytowych w dłuższej perspektywie czasowej. Nie ulega wątpliwości, iż kluczowe znaczenie

\footnotetext{
${ }^{9}$ Zob. uzasadnienie Wyroku Sądu Okręgowego w Warszawie z dnia 27 sierpnia 2012 r., sygn. akt XVII AmC 5344/11, [w:] http://orzeczenia.warszawa.so.gov.pl/details/\$N/154505000005127_ XVII_AmC_005344_2011_Uz_2012-08-27_001 [dostęp: 1.01.2018].

${ }^{10}$ OFIARSKI, Prawo bankowe, s. 494.

${ }^{11}$ Tamże, s. 495.
} 
dla kredytobiorcy ma przede wszystkim wysokość rat spłacanych w poszczególnych ramach czasowych ich spłat. Kredytobiorca zwraca kredytodawcy wykorzystaną sumę kredytu. Trzeba jednak zaznaczyć, że suma kredytu z uwagi na kurs waluty obcej może być wyższa w stosunku do waluty obcej. Mianowicie kredytobiorca może być zobligowany do zwrotu bankowi sumy pierwotnie wykorzystanego kredytu, a nawet może mieć ona wyższą wartość rynkową w czasie spłaty kredytu. W takiej sytuacji klauzula regulująca tzw. spread walutowy określa jedynie fakultatywny mechanizm indeksacyjny głównych świadczeń stron umowy kredytowej. Innymi słowy kształtuje metodę określania rynkowej wartości wydanej i wykorzystanej sumy kredytu w stosunku do walut obcych. Indeksacja walutowa służyć ma bowiem ustaleniu i utrzymywaniu wartości świadczeń w czasie operacji kredytowej $^{12}$. Klauzula dotycząca tzw. spreadu walutowego kreuje, więc mechanizm, mający na celu realizację funkcji waloryzacyjnej, nie rozstrzygając o strukturze, istocie świadczeń stron w związku z umową kredytu indeksowanego ${ }^{13}$.

Niewątpliwie zatem umowa kredytu indeksowanego jest szczególnym typem umowy kredytu bankowego. Kredyt bowiem zostaje udzielony i wypłacony w walucie polskiej, po czym rozliczany jest w walucie obcej. Strony umowy ustalają, że kwota kapitału kredytu wyrażona w walucie polskiej zostanie w drodze indeksacji przeliczona na walutę obcą oraz oprocentowana w adekwatny sposób dla tej waluty. Zatem w momencie wypłaty kwoty kredytu zachodzi podobieństwo do nowacji zobowiązania. W miejsce pierwotnego zobowiązania do zwrotu wskazanej w umowie kwoty w złotych, powstaje zobowiązanie do zwrotu równowartości tej kwoty w walucie indeksacji. Powstaje więc sytuacja analogiczna do kredytobiorcy, który zawarł umowę kredytu denominowanego w walucie obcej oraz kredytobiorcy, który zaciągnął kredyt bezpośrednio w takiej walucie ${ }^{14}$.

\section{KLAUZULA ABUZYWNA}

Zgodnie $\mathrm{z}$ treścią art. $385^{1} \S 1$ Kodeksu cywilnego, postanowienia umowy zawieranej $\mathrm{z}$ konsumentem nieuzgodnione indywidulanie nie wiążą go, jeżeli kształtują jego prawa i obowiązki w sposób sprzeczny z dobrymi obyczajami,

\footnotetext{
${ }^{12}$ Tamże, s. 8.

${ }^{13}$ ZWIĄZEK BANKów POLSKICH, 24 prawdy o kredytach udzielanych we frankach, „Dziennik Gazeta Prawna", 9-11 października 2015 r., nr 197, s. E2-E4.

${ }^{14}$ Zob. uzasadnienie Wyroku Sądu Okręgowego w Warszawie z dnia 22 sierpnia 2016 r., sygn. akt III C 1073/14, [w:] https://orzeczenia.ms.gov.pl/content/\$N/154505000000 903_III_C_001073_ 2014_Uz_2016-08-25_001 [dostęp: 1.01.2018].
} 
rażąco naruszając jego interesy, co nie dotyczy postanowień określających główne świadczenia stron, w tym cenę lub wynagrodzenie, jeśli zostały sformułowane w sposób jednoznaczny.

W celu uzyskania możliwie najlepszej przejrzystości treści powyższego artykułu Kodeksu cywilnego w opracowaniu posłużono się postanowieniem umownym: „Zmiana wysokości oprocentowania może następować także w przypadku zmiany parametrów finansowych rynku pieniężnego i kapitałowego w kraju (lub krajów zrzeszonych w UE), którego waluta jest podstawą indeksacji”, które w związku z wyrokiem Sądu Okręgowego w Warszawie - Sąd Ochrony Konkurencji i Konsumentów z dnia 24 lipca 2012 r. zostało wpisane przez Prezesa Urzędu Ochrony Konkurencji i Konsumenta do rejestru postanowień wzorców umowy uznanych za niedozwolone ${ }^{15}$. Pojęcie ,parametry finansowe rynku pieniężnego i kapitałowego" nie zostało zdefiniowane w umowie ani w regulaminie udzielania pożyczek.

Nawiązując do powyższych uwag, w pierwszej kolejności należy wskazać, że powyższe postanowienie umowne narusza treść art. $385 \S 2$, art. $385^{1} \S 1$, art. $385^{3}$ pkt 10 Kodeksu cywilnego, a także przepisy ustawy Prawo bankowe. Zasady oprocentowania kredytu określała umowa, jednak w świetle art. 76 pkt 1 Prawa bankowego w przypadku stosowania zmiennej stopy oprocentowania w umowie należy określić warunki jej zmiany. Jak wskazano w uzasadnieniu wyroku Sądu Najwyższego z dnia 4 listopada 2011 r., sposób określenia przez bank warunków zmiany stopy procentowej kredytu podlega ocenie z punktu widzenia naruszenia interesów konsumenta i w tym zakresie banki powinny zachować szczególną staranność, w szczególności co do precyzyjnego, jednoznacznego i zrozumiałego dla konsumenta określenia tych warunków ${ }^{16}$.

Analizując poszczególne elementy abuzywności stwierdzić należy, że użycie pojęcia „parametrów finansowych” wskazuje na mnogość tychże czynników. Nie przedstawiono bowiem wyczerpującej listy tych czynników, ani też nie dano możliwości jakiegokolwiek negocjowania. Ponadto niezależnie od arbitralności wyboru wskaźników, w żaden dający się zweryfikować co do jego zachowania sposób nie określono relacji między zmianą poszczególnych i tak już jednostronnie dobieranych parametrów, a zmianą oprocentowania. Ukształtowanie $w$ ten sposób klauzuli umownej, czyniło kredytodawcę jej wyłącznym interpretatorem, przy czym interpretacje były dokonywane jednostronnie i wiązały kredytobiorcę.

\footnotetext{
${ }^{15}$ Zob. wyrok Sądu Okręgowego w Warszawie - Sąd Ochrony Konkurencji i Konsumentów z dnia 24 lipca 2012 r., sygn. akt XVII AmC 285/11, [w:] http://orzeczenia.warszawa.so.gov.pl/ details/\$N/154505000005127_XVII_AmC_000285_2011_Uz_2012-07-24_002 [dostęp: 4.04.2018].

${ }^{16}$ Zob. uzasadnienie wyroku Sądu Najwyższego z dnia 4 listopada 2011 r., sygn. akt I CSK 46/11, [w:] http://sn.pl/Sites/orzecznictwo/Orzeczenia2/I\%20CSK\%2046-11-1.pdf [dostęp: 4.09.2018].
} 
W istocie umowa została tak sformułowana, że stanowi o blankietowym upoważnieniu dla kredytobiorcy do ustalania wysokości oprocentowania. Kredytobiorca nie mógł kontrolować czy choćby przewidywać o ile zmieni się oprocentowanie, skoro omawiana klauzula nie zawiera informacji o sposobie wyliczenia nowej wysokości oprocentowania. Była to zatem sytuacja wprost przewidziana w art. $385^{3}$ pkt 9 Kodeksu cywilnego. Ponadto kwestionowane postanowienie nie było uzgadniane indywidualnie, albowiem konsument nie miał realnego wpływu na ich treść, a jedynie miał możliwość wyboru czy umowę ma wskazanych warunkach podpisać, czy też nie. Indywidualna sytuacja kredytobiorcy miała jedynie wpływ na początkową wysokość oprocentowania, nie zaś na sposób zapisania w umowie mechanizmu jego późniejszych zmian.

Reasumując analiza poszczególnych elementów abuzywności omawianego postanowienia umownego pozwala stwierdzić, że po pierwsze, użycie pojęcia parametrów finansowych rynku pieniężnego i kapitałowego w kraju, którego waluta jest podstawą waloryzacji, jest rażąco ogólnikowe i niezrozumiałe. W świetle art. $385 \S 2$ Kodeksu cywilnego „postanowienia niejednoznaczne tłumaczy się na korzyść konsumenta". Nie jest możliwe wskazanie zamkniętego katalogu takich parametrów. Po drugie, niezależnie od arbitralności wyboru wskaźników, w żaden dający się zweryfikować co do jego zachowania sposób nie określono relacji między zmianą poszczególnych i tak jednostronnie dobieranych parametrów, a zmianą oprocentowania. Ustalenie oprocentowania pozostaje zatem jednostronną decyzją kredytodawcy, nieweryfikowalną pod kątem zgodności zastosowanej metody ustalenia oprocentowania $\mathrm{z}$ procedurą uzgodnioną przez strony. Sąd Najwyższy w przywołanym wyroku podkreślił, iż ,,jednoznaczny oznacza dopuszczający tylko jedną możliwą interpretację, niebudzący wątpliwości, dokładnie określony". Za takie nie można zaś uznać zakwestionowanego postanowienia umownego, którego redakcja była daleka od jednoznaczności i umożliwiała kredytodawcy na dowolną zmianę stopy oprocentowania. Kwestia ta powinna być bowiem wprost określona w umowie kredytowej, tymczasem kredytodawca, konstruując wzorzec umowny odnośnie do postanowień dotyczących oprocentowania, stworzył taką klauzulę umowną, która godzi w równowagę kontraktową.

\section{KRYTERIA USTALANIA KURSU CHF}

W literaturze przedmiotu można spotkać się z poglądem, iż „kredyty frankowe i zasady ich rozliczania są całkowicie zgodne z prawem i z wszelkimi regułami prowadzenia działalności bankowej. Dotyczy to zasady, że potrzebna kredyto- 
biorcy kwota w złotych jest przeliczana na walutę kredytu po kursie kupna tej waluty przez określony bank $\mathrm{z}$ dnia uruchomienia kredytu [...]. Jeżeli więc w umowie kredytowej znajduje się taka klauzula, to nie ma żadnych podstaw prawnych, aby podważać takie postanowienie",17. Nie sposób zgodzić się z powyższą opinią biorąc pod uwagę przede wszystkim wyrok Sądu Okręgowego w Warszawie - Sąd Ochrony Konkurencji i Konsumentów z dnia 19 kwietnia 2016 r., który zadecydował, że „,przeliczenia kredytu na walutę waloryzacji bank dokonuje wg kursu kupna danej waluty z tabeli kursowej banku obowiązującej w dniu i godzinie uruchomienia kredytu" jest postanowieniem niedozwolonym ${ }^{18}$.

Pozwany bank bowiem przyznał sobie prawo do jednostronnego regulowania wysokości rat kredytu waloryzowanego kursem CHF poprzez wyznaczenie w tabelach kursowych kursu sprzedaży franka szwajcarskiego oraz wartości spreadu walutowego (rozumianego jako różnica pomiędzy kursem sprzedaży a kursem zakupu waluty obcej). Istotne jest, iż waloryzacja rat kredytów odbywała się w oparciu o tabele kursowe sporządzone przez pozwany bank i to uprawnienie kredytodawcy polegające na określeniu wysokość kursu sprzedaży CHF nie doznawało żadnych formalnie uregulowanych ograniczeń. Nie został sprecyzowany sposób ustalania kursu wymiany walut wskazanych w tabeli kursów banku. Ponadto analizowane postanowienie nie przewiduje wymogu, aby wysokość kursu ustalonego przez Bank pozostawała $\mathrm{w}$ określonej relacji do aktualnego kursu CHF ukształtowanego przez rynek walutowy lub na przykład kursu średniego publikowanego przez Narodowy Bank Polski. W konsekwencji bank dysponował całkowitą dowolnością w zakresie wyboru kryteriów ustalania kursu CHF w swoich tabelach kursowych, a przez to kształtowania wysokości zobowiązań klientów, których kredyty waloryzowane są kursem CHF.

Mając powyższe na uwadze bez wątpienia, pozwany bank nie zastosował się do zalecenia Komisji Nadzoru Bankowego zawartego w Rekomendacji S dotyczącej dobrych praktyk w zakresie ekspozycji kredytowych zabezpieczonych hipotecznie.

W pkt 5.2.2. Rekomendacji postanowiono, że „w każdej umowie, która dotyczy walutowych ekspozycji kredytowych powinny znaleźć się co najmniej

${ }^{17}$ R. SZEWCZYK, Ekonomiczne, prawne i etyczne aspekty kredytów frankowych, „Bank i Kredyt” 48 (5) 2017, [w:] http://bankikredyt.nbp.pl/content/2017/05/BIK_05_2017_01.pdf [dostęp: 11.04. 2018], s. 461.

${ }^{18}$ Zob. wyrok Sądu Okręgowego w Warszawie - Sąd Ochrony Konkurencji i Konsumenta z dnia 16 kwietnia 2016 r., sygn. akt XVII AmC2939/14, [w:] https://orzeczenia.ms.gov.pl/content. pdffile/\$002fneurocourt\$002fpublished $\$ 002 \mathrm{f} 15 \$ 002 \mathrm{f} 450500 \$ 002 \mathrm{f} 0005127 \$ 002 \mathrm{fAmC} \$ 002 \mathrm{f} 2014 \$ 002 \mathrm{f} 00$ 2939\$002f154505000005127_XVII_AmC_002939_2014_Uz_2016-05-09_001-publ.xml?t:ac=\$N/15 4505000005127_XVII_AmC_002939_2014_Uz_2016-05-09_001 [dostęp: 11.04.2018]. 
zapisy dotyczące sposobów i terminów ustalenia kursu wymiany walut, na podstawie którego w szczególności wyliczana jest kwota uruchamianego kredytu, jego transz i rat kapitałowo-odsetkowych oraz zasad przeliczania na walutę wypłaty i spłaty kredytu" ${ }^{\prime 19}$. W analizowanym postanowieniu umownym nie określono sposobu ustalania kursu sprzedaży CHF, a samo sprecyzowanie momentu waloryzacji nie stanowi wystarczającego zabezpieczenia interesów kredytobiorcy.

\section{ZAKOŃCZENIE}

Ryzyko w przypadku kredytu hipotecznego jest wysokie w związku z długim okresem zobowiązania. Nie ulega wątpliwości, iż kredytobiorca musi liczyć się z możliwością wystąpienia niekorzystnych zmian otoczenia. „W przypadku kredytów hipotecznych waloryzowanych (denominowanych lub indeksowanych) w walucie obcej udzielonych według zmiennej stopy procentowej, koszty obsługi zadłużenia zmieniają się nie tylko na skutek zmian rynkowych stóp procentowych, ale również na skutek zmian kursu waluty indeksacji kredytu” ${ }^{\text {"20 }}$. Warto pamiętać, że dynamiczny rozwój kredytów hipotecznych rozpoczął się w $1996 \mathrm{r}^{21} \mathrm{~W}$ literaturze przedmiotu system kredytów hipotecznych uznaje się za wyjątkowo wrażliwy zarówno na polu makroekonomicznym, jak i mikroekonomicznym, z uwagi m.in. na ryzyko stopy procentowej i czy stabilność rynku finansowego. W doktrynie przeważa stanowisko, iż powinny być spełnione minimalne warunki, by system zaczął poprawnie funkcjonować. Polska jest typowym przykładem kraju, w którym pojawiły się problemy przy budowie systemu kredytów hipotecznych ${ }^{22}$.

Analiza przedstawionego opracowania prowadzi do wniosku, że bez wątpienia umowa kredytu indeksowanego, jak i kredytu denominowanego mieści się w konstrukcji ogólnej umowy kredytu bankowego i stanowi jej możliwy wariant. Oczywiste wydaje się również, że w przypadku korzystania z wzorców umowy następuje narzucenie woli kontrahenta. „W umowie zawieranej na podstawie wzorca umownego trudno jest mówić o konsensusie w takim rozumieniu, w jakim

\footnotetext{
${ }^{19}$ KOMISJA NADZORU BANKOWEGO, Rekomendacja S dotyczaca dobrych praktyk $w$ zakresie ekspozycji kredytowych zabezpieczonych hipotecznie, [w:] https://www.knf.gov.pl/knf/pl/komponenty/ img/rekomendacja_s_8566.pdf [dostęp: 11.04.2018], s. 28.

${ }^{20}$ BAREMBUCH, Kredyt frankowy, s. 809.

${ }^{21}$ J. ŁASZEK, Rozwój i finansowanie sektora nieruchomości w Polsce, „Bezpieczny Bank, Bankowy Fundusz Gwarancyjny” 4 (53) 2013, s. 21.

${ }^{22}$ Tamże, s. 23.
} 
występuje on w umowach indywidualnie negocjowanych" ${ }^{\text {"23 }}$. Nie ulega także wątpliwości, że w istotnej liczbie przypadków kredytodawcy traktowali kredytobiorców sprzecznie z dobrymi obyczajami oraz naruszali ich interesy w sposób rażący, uzależniając ich sytuację wyłącznie od własnych arbitralnych decyzji.

Praca dowodzi w świetle zaprezentowanych przykładów, iż zasadne jest w sytuacji ustalenia abuzywności postanowienia umownego wystąpienie kredytobiorcy na ścieżkę sądową przeciwko kredytodawcy. Warto wówczas oprzeć swoje roszczenie na treści art. $410 \mathrm{w}$ zw. art. $405 \mathrm{i}$ art. $385^{1} \S 1$ Kodeksu cywilnego. Wnioskować należy bowiem, iż skoro niedozwolone postanowienie umowne nie wiąże kredytobiorcy, to brak jest także podstawy do podwyższonych na jego podstawie odsetek.

Należy także zgodzić się z poglądem Rzecznika Finansowego, który podkreślił, że praktyka banków związana z oferowaniem konsumentom umów kredytów walutowych była nakierowana w znacznej mierze na maksymalizację wyniku sprzedażowego. Kredyty walutowe bowiem stanowiły dla sektora bankowego źródło istotnych korzyści finansowych, które w pewnej mierze wynikały ze stosowania w umowach kredytowych postanowień o charakterze abuzywnym $^{24}$. Należy również zgodzić się ze stanowiskiem Komitetu Stabilności Finansowej, iż wszelkie rozwiązania prawne dotyczące powszechnego przewalutowania walutowych kredytów mieszkaniowych są niewskazane. Ustawowe przewalutowanie kredytów mieszkaniowych mogłoby spowodować istotne zagrożenie dla stabilności krajowego systemu finansowego. Warto bowiem w sposób szczególny podkreślić pogląd byłego prezesa Narodowego Banku Polskiego, iż państwo powinno zagwarantować mechanizmy, które zadbają zachować zdrową konkurencję w sektorze finansowym oraz wzmacniać infrastrukturę finansową ${ }^{25}$.

\section{BIBLIOGRAFIA}

ŹRÓDŁA PRAWA

Ustawa z dnia 23 kwietnia 1964 r. - Kodeks cywilny, Dz. U. z 2018 r., poz. 398.

Ustawa z dnia 29 sierpnia 1997 r. Prawo bankowe, Dz. U. z 2017 r., poz. 138.

Ustawa z dnia 29 lipca 2011 r. o zmianie ustawy - Prawo bankowe oraz niektórych innych ustaw, Dz. U. poz. 984.

\footnotetext{
${ }^{23}$ E. ŁĘTOwSKA, Europejskie prawo umów konsumenckich, Warszawa: Wydawnictwo C.H. Beck 2004, s. 255.

${ }^{24}$ RAPORT RZECZNIKA FinANSOWEGO, Analiza prawna, s. 96.

${ }^{25}$ M. BELKA, Dlaczego tylko odkrywać? Lekcja z obecnego kryzysu dla ekonomii i polityki gospodarczej, „Bezpieczny Bank, Bankowy Fundusz Gwarancyjny” 4 (53) 2013, s. 14.
} 


\section{ORZECZNICTWO}

Uzasadnienie wyroku Sąu Najwyższego z dnia 4 listopada 2011 r., sygn. akt I CSK 46/11, [w:] http://sn.pl/Sites/orzecznictwo/Orzeczenia2/I\%20CSK\%2046-11-1.pdf [dostęp: 4.09.2018].

Wyrok Sądu Okręgowego w Warszawie - Sąd Ochrony Konkurencji i Konsumentów z dnia 24 lipca 2012 r., sygn. akt XVII AmC 285/11, [w:] http://orzeczenia.warszawa.so.gov.pl/details/\$N/ 154505000005127_XVII_AmC_000285_2011_Uz_2012-07-24_002 [dostęp: 4.04.2018].

Uzasadnienie wyroku Sądu Okręgowego w Warszawie z dnia 27 sierpnia 2012 r., sygn. akt XVII AmC 5344/11, [w:] http://orzeczenia.warszawa.so.gov.pl/details/\$N/154505000005127_XVII_ AmC_005344_2011_Uz_2012-08-27_001 [dostęp: 1.01.2018].

Wyrok Sądu Okręgowego w Warszawie - Sąd Ochrony Konkurencji i Konsumenta z dnia 16 kwietnia 2016 r., sygn. akt XVII AmC2939/14, [w:] https://orzeczenia.ms.gov.pl/content.pdffile/\$002fneu rocourt $\$ 002$ fpublished $\$ 002 \mathrm{f} 15 \$ 002 \mathrm{f} 450500 \$ 002 \mathrm{f} 0005127 \$ 002 \mathrm{fAmC} \$ 002 \mathrm{f} 2014 \$ 002 \mathrm{f} 002939 \$ 00$ 2f154505000005127_XVII_AmC_002939_2014_Uz_2016-05-09_001-publ.xml?t:ac=\$N/154505 000005127_XVII_AmC_002939_2014_Uz_2016-05-09_001 [dostęp: 11.04.2018].

Uzasadnienie wyroku Sądu Okręgowego w Warszawie z dnia 22 sierpnia 2016 r., sygn. akt III C 1073/14, [w:] https://orzeczenia.ms.gov.pl/content/\$N/154505000000903_III_C_001073_2014 _Uz_2016-08-25_001 [dostęp: 1.01.2018].

\section{LITERATURA}

BAREMBUCH Adam: Kredyt frankowy a kredyt złotowy - perspektywa zmian clash-flow, Finanse, Rynki Finansowe, Ubezpieczenia 82 (2016), nr 4, cz. 2, [w:] http://www.wneiz.pl/nauka _wneiz/ frfu/82-2016/FRFU-82-cz2-805.pdf [dostęp: 9.04.2018], s. 805-820.

BELKA Marek: Dlaczego tylko odkrywać? Lekcje z obecnego kryzysu dla ekonomii i polityki gospodarczej, Bezpieczny Bank, Bankowy Fundusz Gwarancyjny 4 (53) 2013, s. 7-18.

ŁASZEK Jacek: Rozwój i finansowanie sektora nieruchomości w Polsce, Bezpieczny Bank, Bankowy Fundusz Gwarancyjny 4 (53) 2013, s. 19-51.

ŁĘTOWSKA Ewa: Europejskie prawo umów konsumenckich, Warszawa: Wydawnictwo C.H. Beck 2004

OfIARSKI Zbigniew: Prawo bankowe. Komentarz LEX, Warszawa: Wolters Kluwer 2013.

SZEWCZYK Ryszard: Ekonomiczne, prawne i etyczne aspekty kredytów frankowych, Bank $i$ Kredyt 48 (5) 2017, [w:] http://bankikredyt.nbp.pl/content/2017/05/BIK_05_2017_01.pdf [dostęp: 11.04.2018], s. $451-462$.

KOMISJA NADZORU BANKOWEGO, Rekomendacja S dotycząca dobrych praktyk w zakresie ekspozycji kredytowych zabezpieczonych hipotecznie, [w:] https://www.knf.gov.pl/knf/pl/komponenty/ img/rekomendacja_s_8566.pdf [dostęp: 11.04.2018].

RAPORT RZECZNIKA FINANSOWEGO, Analiza prawna wybranych postanowień umownych stosowanych przez banki w umowach kredytów indeksowanych do waluty obcej lub denominowanych w walucie obcej zawieranych z konsumentami, [w:] https://rf.gov.pl/pdf/Raport_RF_Kredyty _walutowe.pdf [dostęp: 1.01.2018].

ZwIĄZEK BANKów POLSKICH, 24 prawdy o kredytach udzielanych we frankach, Dziennik Gazeta Prawna, 9-11 października 2015 r., nr 197, s. E2-E4.

\section{POSTANOWIENIA UMOWY KREDYTU INDEKSOWANEGO DO WALUTY OBCEJ LUB DENOMINOWANEGO W WALUCIE OBCEJ - STUDIUM PROBLEMU}

$$
\text { Streszczenie }
$$

Celem artykułu jest zdefiniowanie niedozwolonego postanowienia umownego na przykładzie umowy o kredyt indeksowany lub denominowanego do waluty innej niż waluta polska. Klauzula 
niedozwolona to możliwość uniknięcia skrajnie niekorzystnych warunków w zawartych umowach. W opracowaniu przedstawiono sytuację kredytobiorców, którzy zaciągnęli kredyt indeksowany do waluty obcej lub denominowany w walucie obcej. Analizę przeprowadzono w oparciu o rzeczywiste niedozwolone postanowienia umowne. Artykuł kończą wnioski dotyczące zasadności roszczeń kredytobiorców.

Słowa kluczowe: umowa kredytu; klauzula abuzywna; kredytobiorca; kredytodawca; roszczenie

\section{PROVISIONS OF THE INDEXED LOAN AGREEMENT TO A FOREIGN CURRENCY OR CURRENCY DENOMINATED IN FOREIGN CURRENCY - A STUDY OF THE PROBLEM}

\section{S u m m ary}

The purpose of the article is to define an unlawful contractual clause on the example of an indexed credit agreement or denominated in a currency other than the Polish currency. The forbidden clause is the possibility to avoid extremely unfavorable conditions in concluded contracts. The elaboration presents the situation of borrowers who have taken a loan indexed to a foreign currency or denominated in a foreign currency. The analysis was based on the actual unlawful contractual provisions. The article ends with conclusions regarding the legitimacy of borrowers' claims.

Key words: loan agreement; abusive clause; borrower; lender; claim 